\title{
Irrigation water management in Southern continental oasis of Tunisia
}

\author{
Zied Haj Amor ${ }^{1}$, Nesma Feki ${ }^{2}$ and Salem Bouri ${ }^{1}$ \\ ${ }^{I}$ Water, Energy and Environment Laboratory, National Engineering School of Sfax, 3038 Sfax, Tunisia \\ ${ }^{2}$ Environmental, Geotechnical and Civil Materials Research Unit, National Engineering School of Sfax, \\ 3038 Sfax, Tunisia
}

\begin{abstract}
Although the available water resource is sufficient, it doesn't manage to satisfy the requirements of practiced crop (mainly date palms) in the small continental oasis Lazala (75 ha) situated in the South of Douz (Southern Tunisia). Indeed, the oasis showed a low frequency of water delivery turn for the whole irrigated surface (especially in summer). This incited us to evaluate the irrigation performance. To reach this objective, a comparative survey of the features of exploited water resource $(60 \mathrm{l} / \mathrm{s})$, the crop water requirements, the proprieties of irrigation network and the water management within the plots has been undertaken. The flow rate measurements that were carried along the hydraulic network and the spatial and temporal following of water management in some plots (experimental plots) during the 2012/13 irrigation season showed a poor overall irrigation efficiency $\left(E_{o}=28.41 \%\right)$, a relatively low water application efficiency $\left(E_{a}=44.6 \%\right)$ and a moderate value of water distribution uniformity $\left(D_{U}=67 \%\right)$ which are related mainly to the context of the region (climatic conditions and soil type), the technical dysfunctions of the hydraulic infrastructure and the individual farmer's practices within the plots (high irrigation duration, absence of water-saving systems in many irrigated areas and the bad land leveling).
\end{abstract}

Keywords: irrigation efficiency, oasis, Southern Tunisia, water management.

\section{Introduction}

Since the beginning of the present century, an intensive irrigated agriculture (oasis systems) has taken an important place in the Tunisian South based essentially on the important production and the enormous export of the dates notably the variety Deglet Nour (Askri et al. 2010). In these arid regions, the oasian agriculture performance is dependent on the efficiency of water distribution and application, especially in the face of increasing water demand, decreasing water availability, and widespread salinity and water logging hazards (Saeed et al. 2002). A perfect irrigation will be therefore a fundamental element for their development and their durability (Omrani et Ouessar, 2009). Usually, the shortest way to obtain this perfect irrigation was the optimizing of water resource use (optimizing during transportation, distribution and application). An effective hydraulic system is the one that succeeded to apply this optimum water dose, that certainly passes by the increase of the offer but also and especially by the improvement of the demand management in agricultural water and its best valorization (Bouaziz et al. 2002).

Irrigation efficiency is a basic element used in irrigation science to characterize hydraulic performance, evaluate irrigation water use, and to promote better or improved use of water resources (Abbasi et Sohrab, 2011). Often, the hydraulic performance of a farm irrigation system is determined by the efficiency with which water is diverted, conveyed, and applied and by the adequacy and uniformity of the application in each field on the farm to evaluate the irrigation system (Kanber et al. 2005). There are several publications describing the procedures and the indicators for evaluating irrigation systems (FAO, 1989). In the South of Tunisia, according to the main proprieties of the oasis (climatic conditions, , irrigation system, components of farming system ,soil type, etc.) that have been identified by many authors (e.g., Sghair, 1995; Kassah, 1996; Louhichi, 1999; Ghazouani et al, 2007; Mekki et al, 2009) usually, the hydraulic indicators of the practice irrigation (surface irrigation) focuses on a set of key performance indicators related to the distribution efficiency $\left(\mathrm{E}_{\mathrm{d}}\right)$, application efficiency $\left(\mathrm{E}_{\mathrm{a}}\right)$ proposed by Allen et al (1997) and water distribution uniformity $\left(\mathrm{D}_{\mathrm{U}}\right)$ proposed by Heermann et al (1990).The water distribution efficiency $\left(\mathrm{E}_{\mathrm{d}}\right)$ is defined as the ratio between the irrigation water that reaches a field to that diverted from the water resource. Usually, the water quantity delivered to the field is smaller than the water quantity diverted from the source. These water losses include canal seepage, canal spills, evaporation losses from canals and leaks in pipelines (Irmak et al. 2011). The application efficiency $\left(E_{a}\right)$ is a general term of how much water is stored within the crop root zone. The distribution uniformity $\left(D_{U}\right)$ is an evaluation of the uniformity of water application over the field. A non-uniform distribution not only can deprive portions of the crop of needed water, but, furthermore, can overirrigate portions of a field, leading to water-logging, plant injury, salinization, and transport of chemicals to the ground water (Solomon, 1983). The follow-up of these 
indicators on a spatial and temporal scale is a previous condition for a precise assessment of the irrigation performance.

In this context, the present study aimed to examine if the actual management of water resource in the community-managed irrigation scheme Lazala situated in the South of Douz (Southern Tunisia) contributes or not to a perfect irrigation. We try then to determine the irrigation efficiency and putting in light the main constraints for a good hydraulic working of the perimeter. The study was conducted during the agricultural year (2012/2013). The global aim was the valorization of water resource in the study region.

\section{Location and environmental conditions of the study area}

\section{Materials And Methods}

Lazala system is a recent oasis (created in 1998) located $11 \mathrm{Km}$ Southwest of Douz in the South of Kebili governorate (Southern Tunisia). It lies between $8.27^{\circ}$ to $8.29^{\circ} \mathrm{N}$ latitude and $33.24^{\circ}$ to $33.26^{\circ} \mathrm{E}$ longitude. It is delimited in the North and East sides by the sandy dunes of the Great Erg Oriental, in the South by the Elhsay oases and in the West by the Elmhalhal village (figure 1). In 2012, the oasis system covered a net area of 75 ha parceled into 150 farming plots. The area of every plot is 0.50 ha. The plot is a rectangular area of land (typically $100 \mathrm{~m} \times 50 \mathrm{~m}$ ) composed of 40 to 50 irrigation basins planted mainly with date palm trees.

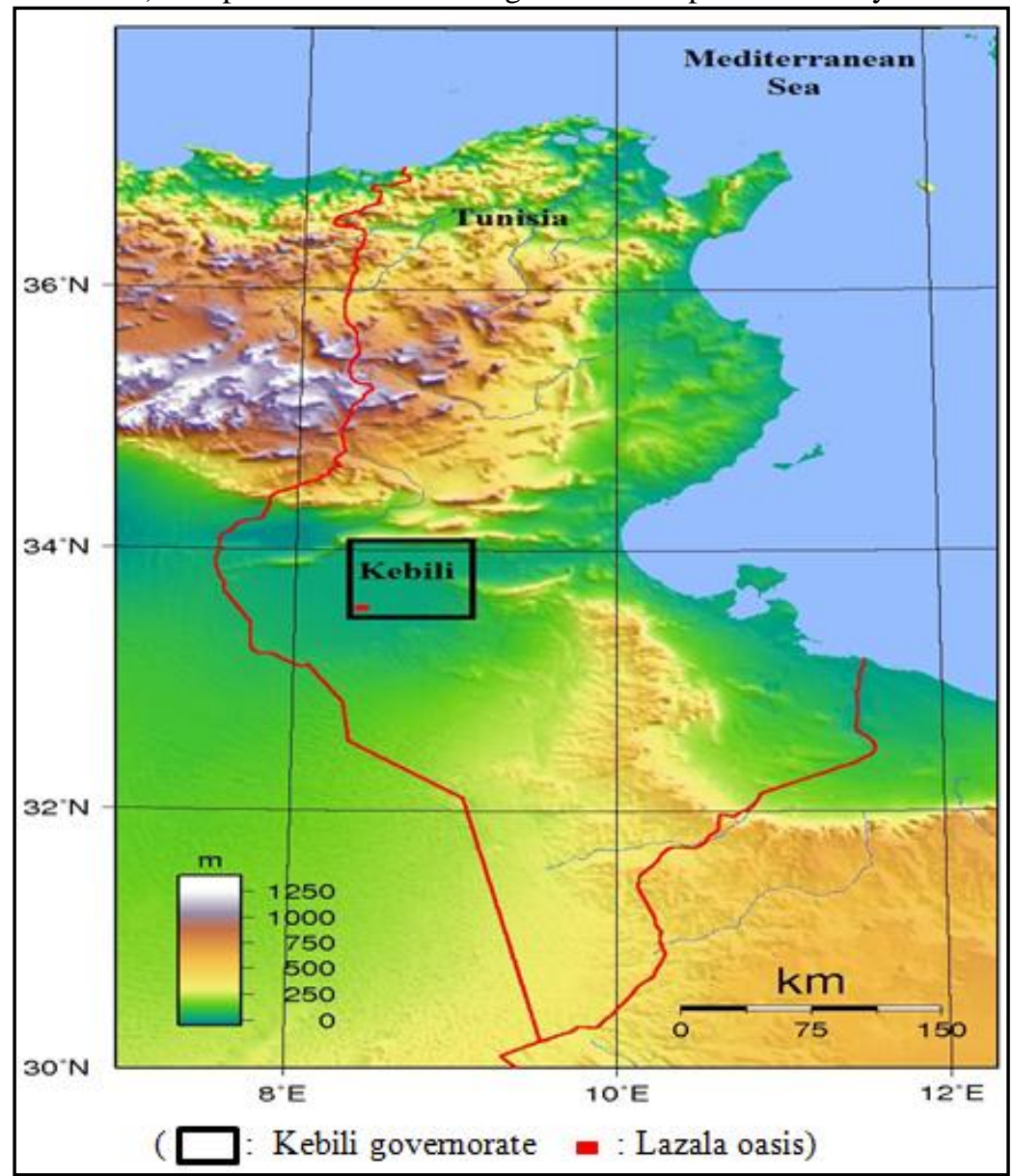

Figure 1- Localization of the Lazala oasis

The oasian irrigation scheme Lazala is characterized by desert climate (less than $80 \mathrm{~mm}$ of rains per year, important variations in temperature, a considerable evapotranspiration that can reach $2000 \mathrm{~mm}$ per year and active wind marked by strong winds of sand in the spring and the sirocco (hot wind) in the summer) (Sghaier, 1999).

Soil resources covering the oasis land were affected by salinization problem, gypsum dynamics and waterlogging phenomenon. A very affected zone by the salinization and waterlogging extends on the Central and the West part of the oasis, which characterized by a low topography and by a network of little maintained drainage. The East zone which characterized by a high topography was affected especially by the salinization at the surface horizons. The excessive salinity and the important degree of waterlogging observed in these soils are related mainly to the low water irrigation quality and the rising of the underground water table (Marlet et al, 2007). Over the twelve soil profiles obtained, the soil of the studied area has a sandy to sandy gypseous texture 
near the surface (the mean rate of gypsum is $35 \%$ ). For the deeper layers, the sand is finer and the dominance of gypsum is less important (the medium is 10\%).

On the other hand, the irrigation of the practiced plantation is assured by a deep geothermal artesian well (2020 $\mathrm{m})$ with a depth of $2020 \mathrm{~m}$ and temperature of $72^{\circ} \mathrm{C}$ (CI.18) screened in the Continental Intercalary aquifer that delivers $60 \mathrm{l} \mathrm{s}^{-1}$. This unconfined groundwater constitutes the deepest and the largest aquifer system in the Southern Tunisia (SASS, 2003). Mean temperature of cool water is $35^{\circ} \mathrm{C}$ whereas salinity is $4.2 \mathrm{~g} \mathrm{l}^{-1}$.

The irrigated area is equipped with a drainage network consisting of $1.6 \mathrm{~m}$ deep ditches spaced $200 \mathrm{~m}$ apart. The drainage collectors' end is installed in the salt depression Sebkha Elhsay (South of Douz) where the level of land is slightly lower to the one of the plots.

Furthermore, in the study area, the date palm trees (Phoenix dactylifera) and the fodder crops constitute the main components of the farming system. The date palms have nearly the same age (the average age is 12 years) and nearly the same degree of production (weak production). For the fodder crops, they are cultivated for the food needs of animals (especially dromedary, sheep and goats).

\section{Hydraulic network}

The distribution of irrigation water is made by repression of the well. The water is delivered first toward the cooling system (atmospheric cooling towers) then toward a concrete distribution box of $30 \mathrm{~m}^{3}$ of capacity. The underground pipelines joining the well, the cooling system and the distribution box constitute the primary irrigation network (or adduction network). From the distribution box, three irrigation antennas (secondary network) left to irrigate 3 sectors nearly equal in size (20 1/s for each antenna). This secondary irrigation network is formed by PVC pipes supported in half circular concrete canals. From each boundary marker of the watering antennas, a water delivery turn will be practiced between the different farmers where each one will get irrigation duration proportional to the irrigated surface (the irrigation duration was fixed to 9 hours of water per hectare every month). This turn is assured by a tertiary network formed by open concrete canals. Surface irrigation by flooding is the main irrigation method used in the oasis. At farming plot level, the irrigation system includes a series of small level basins. Water fills one basin and then overflows to other basins in the plot. Irrigation water is conveyed from the tertiary network to these basins through small ground earthen canals called "suqyyus" or by PVC pipes (in a few plots).

The main properties of the constituents of the hydraulic network were illustrated in figure 2.

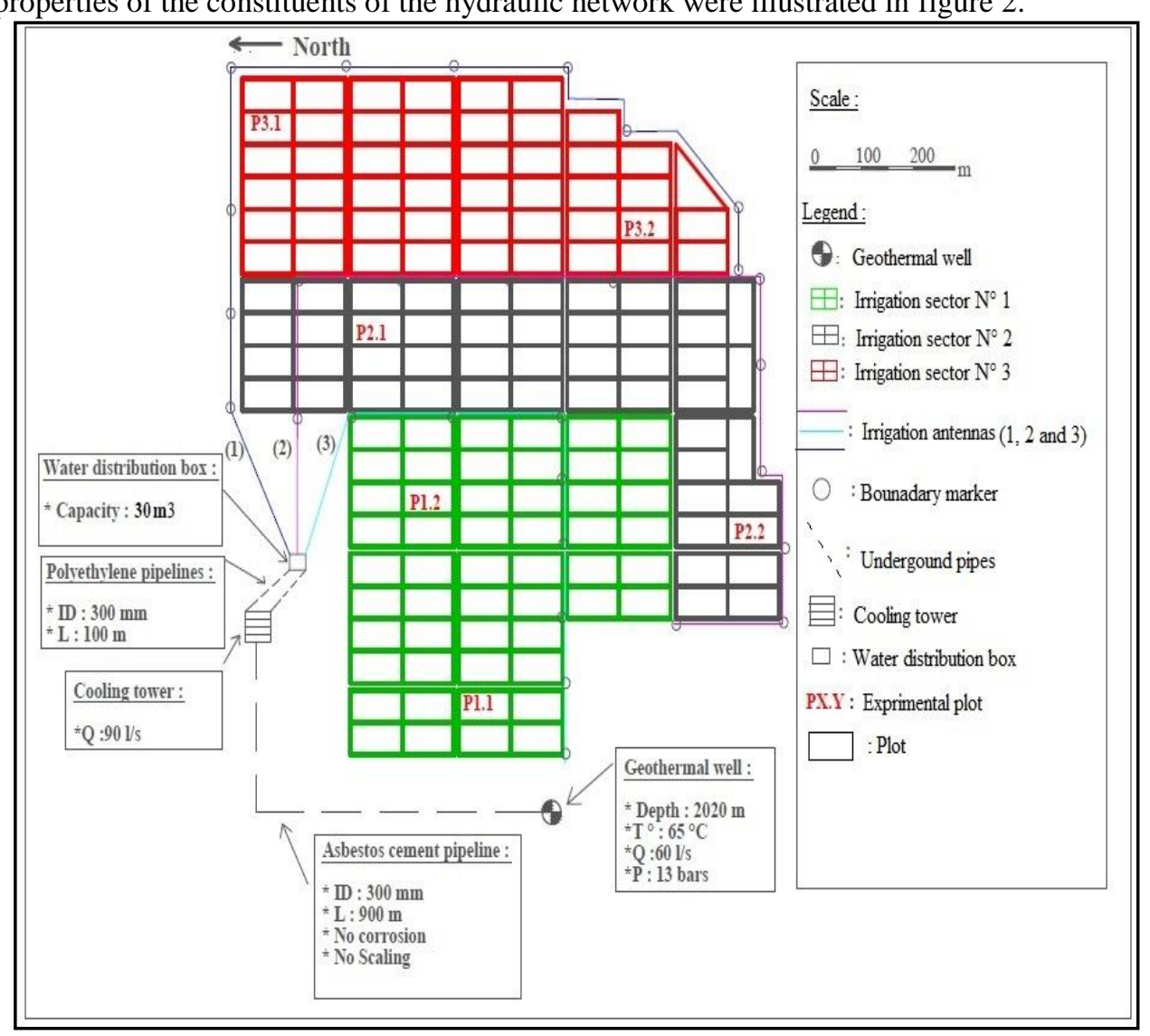

Figure 2- Land plot plan of Lazala oasis and the hydraulic network 


\section{Problematic of irrigation and protocol of measure}

In the 2011/12 irrigation season, although, the exploited water resource was important (60 1/s), the irrigated area was small (75 ha), the extension of new plantations outside the former limits of the oasis was neglected, the farming system (especially date palm trees) relatively doesn't require a lot of irrigation water (Liebenbag et Zaid, 2002) and the plantation density was moderate (90 plants/ha), the studied perimeter showed a low frequency of water delivery turn for the all irrigated sectors in summer and winter seasons (Table 1).

Table 1- Mean irrigation frequencies in Lazala oasis in the 2011/12 irrigation season (Number of irrigated plots: 150, number of irrigation events: 1924)

\begin{tabular}{|c|c|c|c|c|c|c|}
\hline \multirow{2}{*}{$\begin{array}{c}\text { Irrigation } \\
\text { sector }\end{array}$} & $\begin{array}{c}\text { Official irrigated area } \\
\text { (ha) }\end{array}$ & $\begin{array}{c}\text { Actual irrigated area } \\
\text { (ha) }\end{array}$ & $\begin{array}{c}\text { Number of } \\
\text { plots }\end{array}$ & \multicolumn{3}{|c|}{ Irrigation interval (days) } \\
\cline { 3 - 6 } & 24 & 26 & 52 & 18 & $45(+150 \%)$ & $35(+94 \%)$ \\
\hline 1 & 24 & 25 & 49 & 18 & $24(+33 \%)$ & $19(+05 \%)$ \\
\hline 3 & 24 & 24 & 48 & 18 & $22(+22 \%)$ & $20(+11 \%)$ \\
\hline
\end{tabular}

Consequently, it is important to seek the main causes of this problem. It is necessary thus to check first the well capacity (step 1) and last measure the hydraulic performance indicators related to irrigation efficiency according to various processes ( $\operatorname{step} 2$ ).

Step1: check of well capacity

We try in the first step to compare the available water at the irrigation source (artesian well with flow rate of $60 \mathrm{l} / \mathrm{s}$ ) to the crop irrigation water requirement (IR). The latter was determined by the following formula (equation 1):

Where:

$$
\text { IR }=\frac{\left(\frac{N I R}{E d}\right)+(N I R \times L r)}{E a} \quad(\text { Equation 1) }
$$

IR. crop irrigation water requirement at irrigation source $\left(\mathrm{m}^{3} / \mathrm{ha}\right)$

NIR: the net irrigation water or the irrigation water amount to be applied to the soil $\left(\mathrm{m}^{3} / \mathrm{ha}\right)$

$\mathrm{E}_{\mathrm{d}: \text { water distribution efficiency }(\%)}$

$\mathrm{E}_{\mathrm{a}}$ : water application efficiency $(\%)$

$\mathrm{L}_{\mathrm{r}:}$ the leaching requirement $(\%)$

The crop water requirement at the plot (NIR) have been estimated by the results obtained following the irrigation tests of date palms done by the Research Center in Use of Saline water to Irrigation from 1964 to 1969 in the Tozeur oases (similar farming system for our zone) (CRUESI,1970). The water distribution efficiency $\left(E_{d}\right)$ and the water application efficiency $\left(E_{a}\right)$ are fixed respectively to $85 \%$ and $80 \%$. The necessary leaching requirement $\left(\mathrm{L}_{\mathrm{r}}\right)$ was estimated at $6 \%$ by the following formula (Rhodas, 1974) (equation 2):

where:

$$
\boldsymbol{L r}=\frac{\mathrm{ECw}}{((5 \mathrm{ECe})-\mathrm{ECw})}
$$

(Equation 2)

Lr: the minimum leaching requirement needed to control salts within the tolerance (ECe) of the crop with ordinary surface methods of irrigation $(\%)$.

ECw: electrical conductivity of the applied irrigation water in $\mathrm{ds} / \mathrm{m}$.

ECe: average electrical conductivity soil tolerated by the crop as measured on a soil saturation extract (ds/m).

In our case: $\mathrm{EC}_{\mathrm{w}}=6.5 \mathrm{ds} / \mathrm{m}$ and $\mathrm{EC}_{\mathrm{e}}=23 \mathrm{ds} / \mathrm{m}$.

Step 2: measurement of the hydraulic performance indicators

In this step, we have to determine firstly the efficiency of utilizing water resource and the distribution efficiency $\left(E_{d}\right)$, lastly characterize the water management in some plots (calculate the water application efficiency $\left(E_{a}\right)$, the distribution uniformity $\left(\mathrm{D}_{\mathrm{U}}\right)$ and compare the applied doses to the required water doses) and finally deduct the overall irrigation efficiency $\left(\mathrm{E}_{\mathrm{o}}\right)$ for the whole irrigation system.

- Utilization of water resource :

The efficiency of utilizing water resource was estimated on the basis of irrigation breaks stocked by the farmers' groupment from September 2012 to August 2013 (2012/13 irrigation season).

- Distribution efficiency $\left(\mathrm{E}_{\mathrm{d}}\right)$ :

The distribution efficiency $\mathrm{E}_{\mathrm{d}}$ is expressed as (equation 3):

$$
\text { Ed }=\text { Ed1 } \times \text { Ed2 } \times \text { Ed3 } \quad(\text { Equation 3) }
$$

where:

$E_{d}$ : water distribution efficiency of the whole irrigation network $(\%)$.

$\mathrm{E}_{\mathrm{d} 1}$ : water distribution efficiency of the primary irrigation network (\%). 


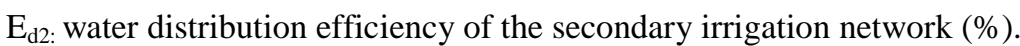

$\mathrm{E}_{\mathrm{d} 3}$ : water distribution efficiency of the tertiary irrigation network (\%).

The efficiencies of the secondary irrigation network $\left(\mathrm{E}_{\mathrm{d} 2}\right)$ and the tertiary irrigation network $\left(E_{\mathrm{d} 3}\right)$ were evaluated by flow rate measurements along the 2012/13 irrigation season. The measures were done by an ultrasonic flow meter every two months for every irrigation sector. The points that have been chosen for these measurements are the 2 latter boundary markers of each irrigation network.

- Characterization of water management within plots:

A total of six plots (figure 2) conducted by farmers using their usual practices were selected for analysis of water management. The selection of these experimental sites sample was based on the variability of soil texture, the size of irrigation basins, the type of canal irrigation system (PVC pipes or earthen canals) and the way of soil management (Table 2). Our objective is the integration of all factors may have impacts on the parameters to measure. For every experimental plot, only one irrigation basin has been selected to achieve the measurements. For each basin, the all irrigation events along the 2012/13 irrigation season have been followed. The illustrated results were the mean values of measured parameters.

Table 2- Properties of the experimental plots

\begin{tabular}{|c|c|c|c|c|c|c|}
\hline Plot & $\mathrm{P}_{1.1}$ & $\mathrm{P}_{1.2}$ & $\mathrm{P}_{2.1}$ & $\mathrm{P}_{2.2}$ & $\mathrm{P}_{3.1}$ & $\mathrm{P}_{3.2}$ \\
\hline Surface $\left(\mathrm{m}^{2}\right)$ & 0.5 & 0.5 & 0.5 & 0.5 & 0.5 & 0.5 \\
\hline Soil texture & Gypseous & Sandy & Clayey sand & Gypseous & Gypseous & Gypseous \\
\hline Canal system of irrigation & Earthen & PVC pipes & Earthen & PVC pipes & Earthen & Earthen \\
\hline Total length of earth canals $(\mathrm{m})$ & 190 & - & 170 & - & 120 & 180 \\
\hline Surface of irrigation basin $\left(\mathrm{m}^{2}\right)$ & 38 & 27 & 38 & 36 & 36 & 56 \\
\hline Soil management & Bad & Good & Moderate & Good & Good & Bad \\
\hline Main crop production & Date palms & Date palms & Date palms & Date palms & Date palms & Date palms \\
\hline
\end{tabular}

The main measured parameters in these experimental plots were: the water application efficiency $\left(E_{a}\right)$, the distribution uniformity $\left(\mathrm{D}_{\mathrm{U}}\right)$, the applied water (in the root zone) and the required water doses.

The water application efficiency (Ea) was calculated according to method of Burt et al. (1997) (equation 4):

where:

$$
\mathrm{Ea}=\left(\frac{\mathrm{Vs}}{\mathrm{Vf}}\right) * 100 \quad(\text { Equation } 4)
$$

Ea: water application efficiency (\%).

$\mathrm{V}_{\mathrm{s}}$ : volume of irrigation water stored in the root zone $(\mathrm{mm})$.

$\mathrm{V}_{\mathrm{f}}$ : volume of irrigation water delivered to the plot $(\mathrm{mm})$.

The distribution uniformity $\left(D_{U}\right)$ was determined by the method of Heermann et al (1990) (equation 5):

$$
\mathrm{Du}=\left(\frac{\mathrm{Diq}}{\mathrm{Dav}}\right) * 100 \quad(\text { Equation 5) }
$$

where:

$\mathrm{D}_{\mathrm{U}}$ : water distribution efficiency $(\%)$

$\mathrm{D}_{\mathrm{iq}}$ : average depth of water infiltrated in the low one quarter of the field (mm)

$\mathrm{D}_{\mathrm{av}}$ : average depth of water infiltrated over the field (mm)

The calculation of the two latter parameters $\left(E_{a}\right.$ and $\left.D_{U}\right)$ requires measurement of flow rates (at the top of plots and at the top of each irrigation basin), irrigation water stored in the root zone and applied water. The flow rates at the top of plots were determined by the direct measurement of flow method (the ratio of a known water volume to a determined irrigation duration), whereas the flows at the top of irrigation basin and in the earth canals were determined by discharge measures. The follow-up of the water stocked in the root zone (before and after each irrigation event) is realized by gravimetric method. Three sites of measure have been selected (the root depth was $100 \mathrm{~cm}$ ): the upstream, the median, and the downstream of every experimental irrigation basin. The illustrated result was the mean of these three measures.

The applied water was determined by the following formula (equation 6):

$$
\text { Applied water }(\mathbf{m m})=\frac{(\text { flow rate }(\mathrm{l} / \mathrm{s}) \times \text { irrigation time }(\mathrm{s}))}{\text { surface of irrigation basin }(\mathrm{m} 2)} \quad \text { (Equation 6) }
$$

Overall irrigation efficiency $\left(\mathrm{E}_{\mathrm{o}}\right)$ :

The overall irrigation efficiency represents the efficiency of the entire irrigation system (Irmak et al. 2011). It's calculated by multiplying the efficiencies of the water source, water distribution and water application (equation 7):

where:

$$
\text { Eo }=\mathrm{Es} \times \mathrm{Ed} \times \mathrm{Ea} \quad(\text { Equation7) }
$$


Es: the overall irrigation efficiency (\%).

Es: the water source efficiency (\%).

$\mathrm{E}_{\mathrm{d}}$ : the water distribution efficiency (\%).

$\mathrm{E}_{\mathrm{a}}$ : the water application efficiency $(\%)$.

\section{Results And Discussion}

\section{Availability of irrigation water and crop water requirements}

The estimation of the crop water requirements (date palms and fodder crops) and the calculation of the artesian well capacity $(60 \mathrm{l} / \mathrm{s})$ showed that along the agricultural year (2012/2013) the irrigation source was capable of supplying the crop water requirements enough (figure 3 ). Therefore, the irrigation problematic is related to the water distribution network and the water management in the plots.

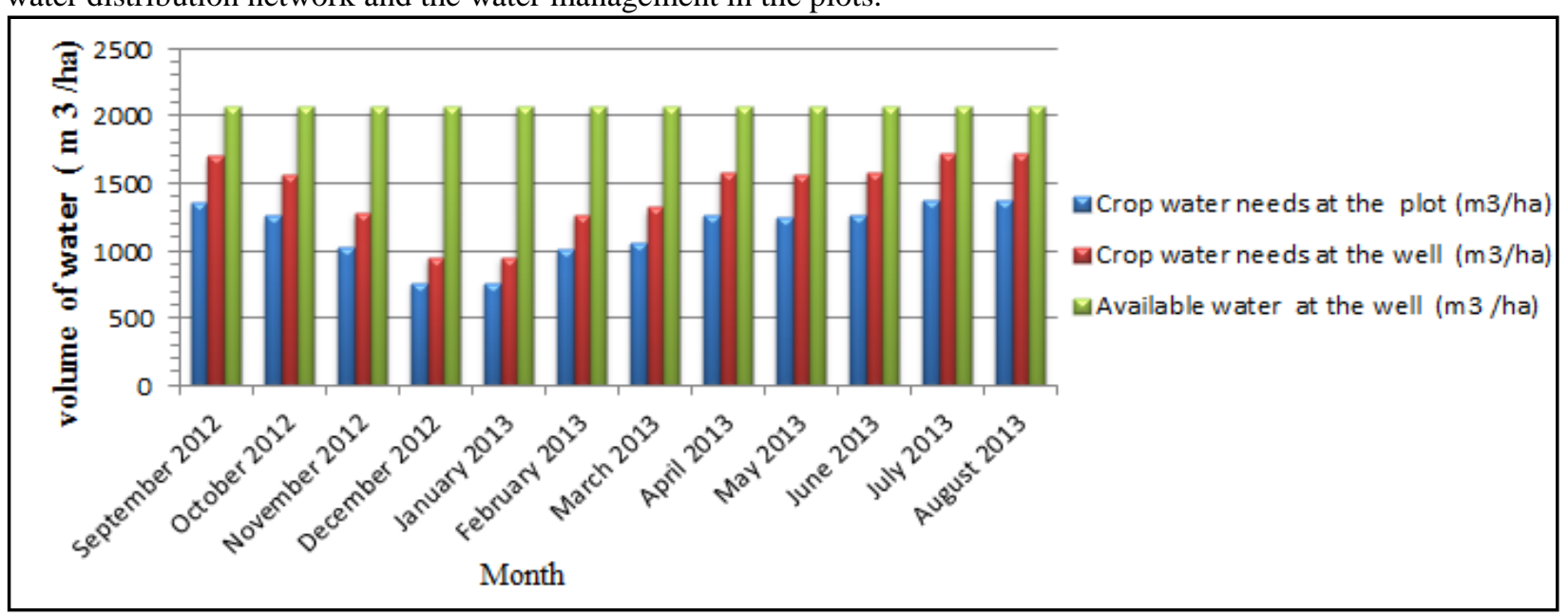

Figure 3-Availability of irrigation water and crop water requirements

\section{Utilization of water resource}

Unlike a pumped drilling, the artesian well doesn't stop to function in the absence of irrigation (irrigation breaks). This generates often lost flows if the needs of irrigation are weak. For the agricultural year $(2012 / 2013)$, the loss flows were estimated at $5.8 \%$ whereas the mean efficiency at the source $\left(\mathrm{E}_{\mathrm{s}}\right)$ was $94.2 \%$ (table 4).

Table 4- Evaluation of water losses at the artesian well

\begin{tabular}{|l|c|c|c|c|}
\hline Period & $09 / 12-11 / 12$ & $12 / 12-02 / 13$ & $03 / 13-05 / 13$ & $06 / 13-08 / 13$ \\
\hline Irrigation hours $(\mathrm{h})$ & 2050 & 1915 & 2070 & 2104 \\
\hline Irrigation breaks $(\mathrm{h})$ & 110 & 245 & 90 & 56 \\
\hline supply water $\left(\mathrm{m}^{3}\right)$ & 466560 & 466560 & 466560 & 466560 \\
\hline Lost flows $\left(\mathrm{m}^{3}\right)$ & 23760 & 52920 & 19440 & 12096 \\
\hline Loss rate $(\%)$ & 5.09 & 11.34 & 4.17 & 2.59 \\
\hline Mean water losses : $5.80 \%$ & & \\
\hline Mean efficiency $\left(\mathrm{E}_{\mathrm{s})}: 94.2 \%\right.$ &
\end{tabular}

3. Water distribution efficiency $\left(E_{d}\right)$

\subsection{Primary irrigation network efficiency}

With a perfect tightness, the pipe leaks at the water adduction network are hopeless, then, the efficiency of the primary network is $100 \%\left(\mathrm{E}_{\mathrm{d} 1}=100 \%\right)$.

\subsection{Secondary irrigation network efficiency}

For every irrigation antenna, the theoretical flow rate that is fixed at $20 \mathrm{l} / \mathrm{s}$ has never been reached. The value intervals are $13.9-15.9 \mathrm{l} / \mathrm{s}, 13.2-15.1 \mathrm{l} / \mathrm{s}$ and $13.3-15.8 \mathrm{l} / \mathrm{s}$ for the irrigation antennas 1,2 and 3 respectively (figure 4). 


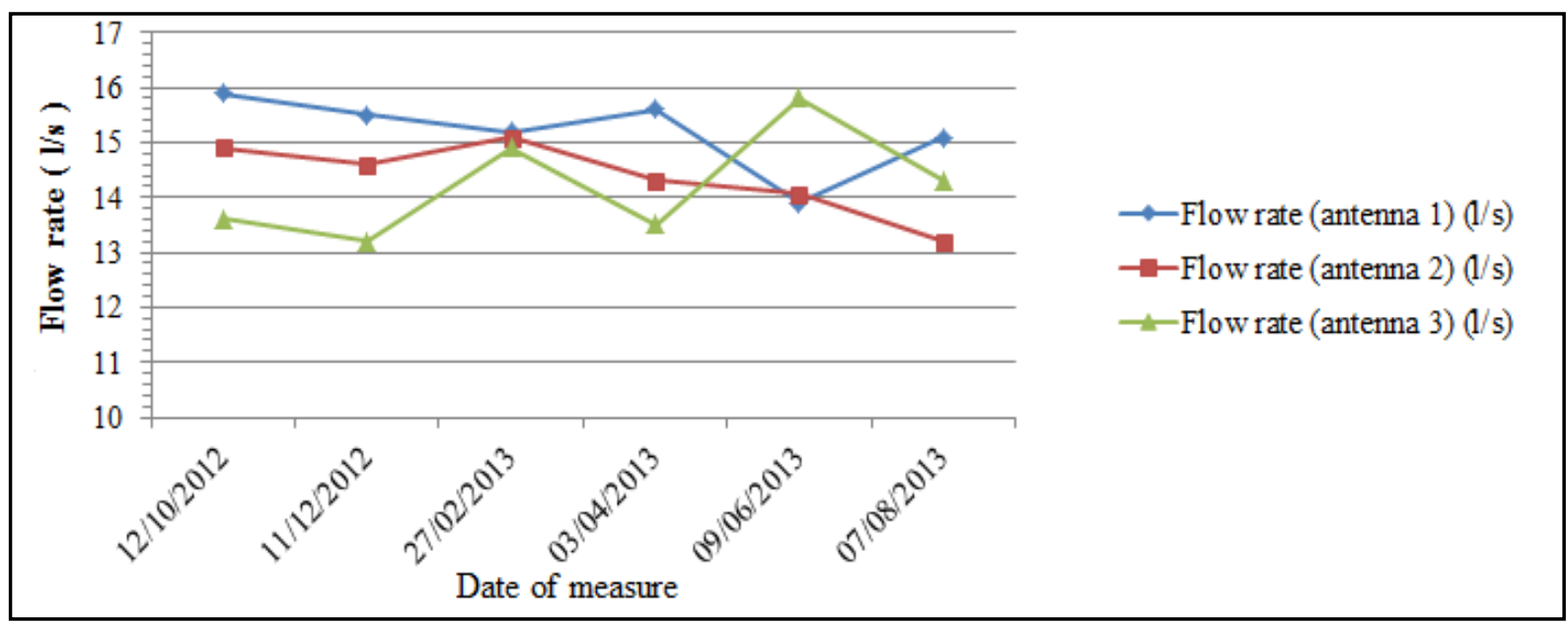

Figure 4- Mean flow rate of the irrigation antennas during the agricultural year (2012/2013)

The recorded efficiencies are relatively low for the three antennas (figure 5). The average efficiency adapted for the whole perimeter is $73 \%\left(\mathrm{E}_{\mathrm{d} 2}=73 \%\right)$ with a maximum of $79.5 \%$ for the first antenna, $75.5 \%$ for the second antenna and $74.5 \%$ for the third antenna.

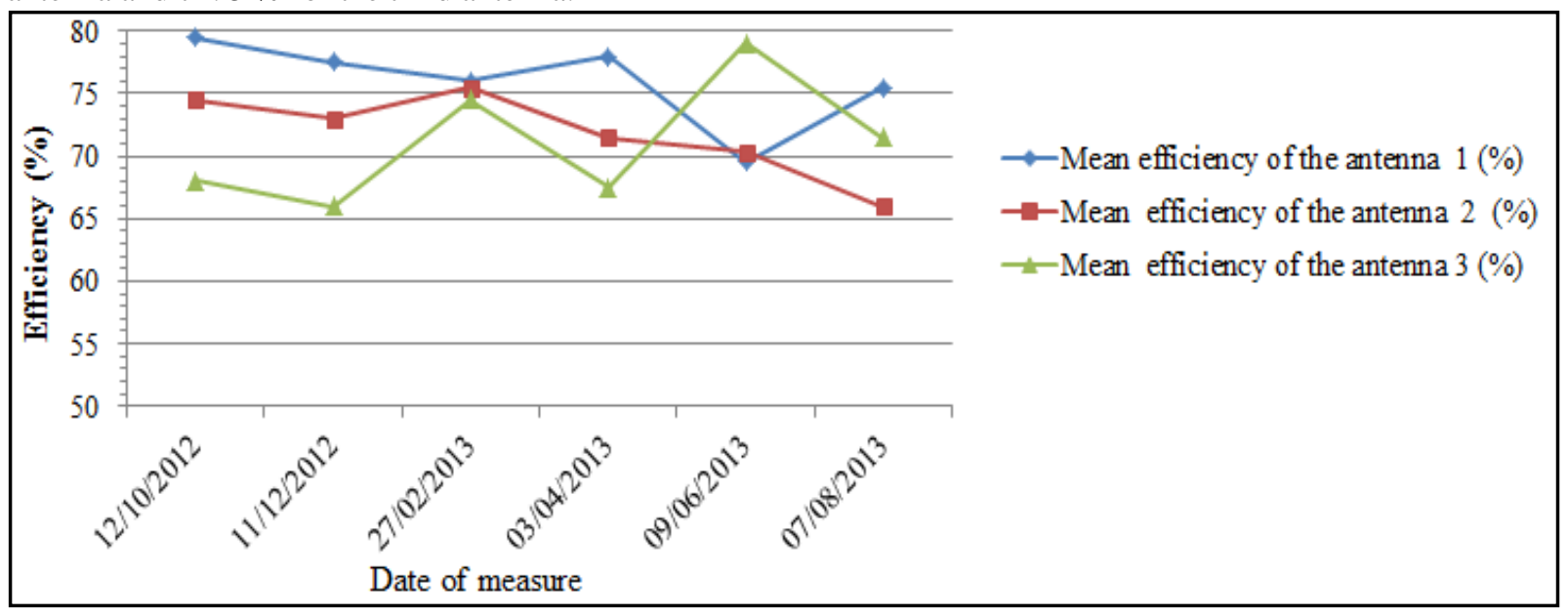

Figure 5- Temporal evolution of the mean efficiencies for the irrigation antennas

The results reflect essentially the bad state of the hydraulic infrastructures situated upstream the boundary markers. Indeed, important water leak is caused during the distribution of water especially at the adjustment between the sections constituting the irrigation antennas (weak tightness).

\subsection{Tertiary irrigation network efficiency}

The totality of this network is arranged in concrete canals joining the irrigation antennas to the farming plots. Water losses and the average efficiencies were calculated for a length of $280 \mathrm{~m}$ that corresponds to the maximal length of the cannels. The mean efficiency is estimated at $92.66 \%$ (figure 6).

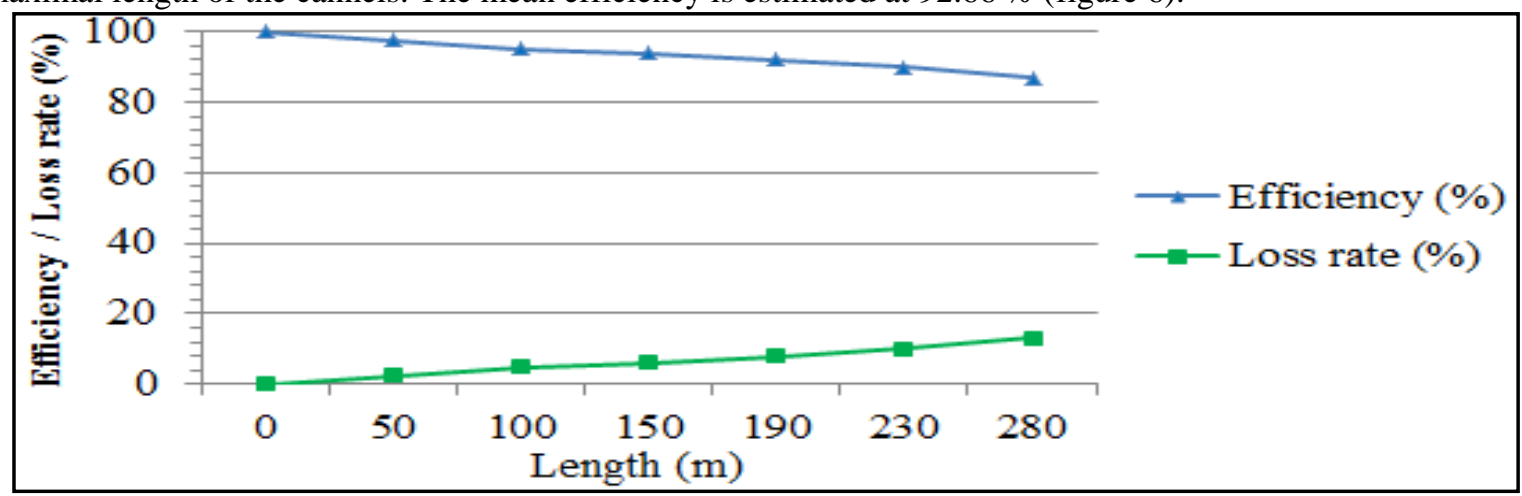

Figure 6-Spatial evolution of the losses and the efficiencies of the tertiary irrigation network

The water losses recorded in this network are mainly related to the bad state of the canals that, although they are constructed in reinforced concrete, they don't stop to show important flights. This is due to the fast deterioration 
of their partitions under the climatic conditions effects (especially the high temperature), the distributed water quality (often saline water) and the growth of logging water phenomenon accompanied often by soil salinity (Gharbi, 2010).

With mean values of $\mathrm{E}_{\mathrm{d} 1}, \mathrm{E}_{\mathrm{d} 2}$ and $\mathrm{E}_{\mathrm{d} 3}$ equal to $100 \%, 73 \%$ and $92.66 \%$ respectively, the water distribution efficiency $\mathrm{E}_{\mathrm{d}}$ was evaluated at $67.64 \%$. This means that the farming plots will receive only $67.64 \%$ of the available water at the well. It's a feeble percentage that reflects an important water loss from the irrigation source to the plots.

\section{Water management in the plots}

Performance of the irrigation events under normal farmer control was poor, with the average application efficiency $\left(\mathrm{E}_{\mathrm{a}}\right)$ a low $45 \%$ and an average water distribution uniformity of $67 \%$ (Table 6).

Table 6- Evaluation of water management parameters in experimental irrigation basins

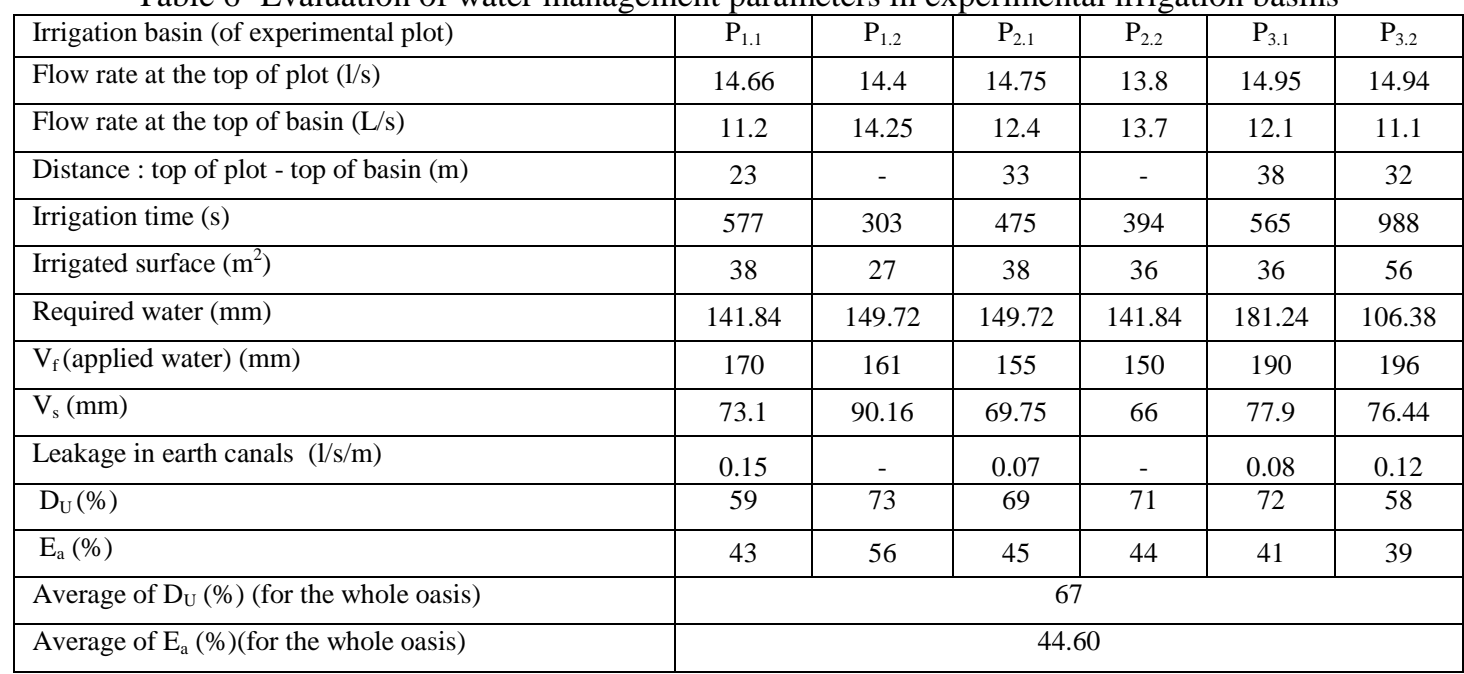

The decrease of the flow rates delivered to the irrigation basins has a relationship with: the low water distribution efficiency $\left(\mathrm{E}_{\mathrm{d}}=67 \%\right)$, the water losses within the earth canals (the main causes are the high infiltration of the sandy soil and the insufficient transit capacity of this canals) and the absence of water saving systems (PVC pipes) in some plots.

According to the classification indicated by Irmak et al (2011) and the mean value of distribution uniformity $\left(D_{U}=67 \%\right)$, the irrigation uniformity in the study oasis would be classified in the "second" class $(60 \%-80 \%)$. This class indicates that the application is relatively uniform over the entire field. At the $\mathrm{P}_{1.1}$ and $\mathrm{P}_{3.2}$ plots, the irrigation water is unevenly distributed $\left(\mathrm{D}_{\mathrm{U}}<60 \%\right)$. This weak result is related to the bad land levelling of irrigation basins, the hydraulic proprieties of the distribution network (unimportant flow rates) and the differences in opportunity time for infiltration caused by advance and recession. The recorded values vary from $58 \%$ for the basin $\mathrm{P}_{3.2}$ characterized by an important dimension $\left(56 \mathrm{~m}^{2}\right)$ to $73 \%$ for the smallest basin $\mathrm{P}_{1.2}(27$ $\mathrm{m}^{2}$ ) that shows a good soil management. Therefore, the distribution uniformity is also influenced by the dimension of the basin plot and the soil management (land leveling). A good land leveling (a uniform grade in the direction of water flow) will be like an indispensable condition to assure the irrigation uniformity and to improve the application efficiency. Indeed, without good distribution uniformity, it is impossible to irrigate efficiently; parts of the plot will be either over-irrigated or under-irrigated (Haman, 2003).

With a mean value of the water application efficiency $\left(\mathrm{E}_{\mathrm{a}}=44.6 \%\right)$ and according to the "typical" application efficiencies identified by many authors (e.g., Merriam and Keller, 1978; Louhichi, 1999) the irrigation would be described as relatively inefficient. The most elevated efficiency $\left(\mathrm{E}_{\mathrm{a}}=56 \%\right)$ is noted at the smallest basin plot $\left(\mathrm{P}_{1.2}\right)$ characterized by a sandy soil, a high water distribution uniformity $\left(\mathrm{D}_{\mathrm{U}}=73 \%\right)$, an important delivered water at the head of irrigation basin $(14.25 \mathrm{l} / \mathrm{s})$ and a good soil management (good land levelling). The lower efficiencies $\left(E_{a}<45 \%\right)$ recorded in the experimental areas are functions of many reasons. We note the weak amount of available water at the plot, the water losses during supply of irrigation source inside the plots (cases of earthen canals), the bad water distribution (cases of $P_{1.1}$ and $P_{3.2}$ plots), the water percolation below the root zone and also the context of the region. Indeed, due to the climatic conditions of the south-western Tunisia oasis (rare rainfall and high evaporation), the quality of delivered water (excess of soluble salts), and the dysfunction of drainage system and the soil type (saline soil with high percentage of gypsum) the volume of stored irrigation water in the root zone is frequently unimportant. If the percentage of gypsum is important (especially at deep soil horizons) the quantity of water that can be stored in the root zone may become marginal. A lower water- 
holding capacity within the root zone makes it more difficult to apply irrigation water efficiently. Consequently, the percolation losses into the gypsic subsoil tend to increase (Alphen et Romero, 1971).

\section{5. "The applied water - The required water" relation}

Knowing how much water is applied during each irrigation event is a fundamental element to good management. The applied water should be always comparing to required water (water crop needs) in order to judge the irrigation performance. In our study, this comparison permits to distinguish noted overdoses for all the plots (figure 7). The most important overdoses are recorded at the basin $\mathrm{P}_{3.2}$ with a value of $91 \mathrm{~mm}$ (overdose of $86 \%)$.

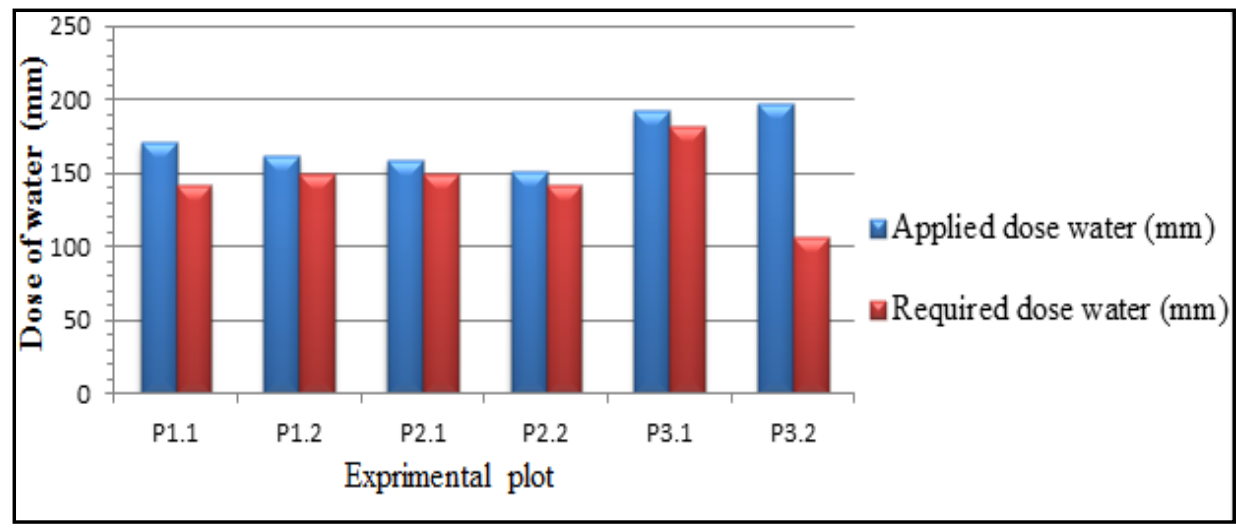

Figure 7- Histogram of applied doses and required doses water in the plots

Minimizing the application of excess water, requires good irrigation scheduling (knowing when, how and how much water to apply) and knowing how water is being applied by the irrigation system.

The main causes of these important applied waters are the bad skills of farmers (not knowing how much water to apply) and the non-respect of the irrigation duration that is fixed by the Water Users' Association (GDA). Indeed, after collecting of all the irrigation durations for the all plots along the period of study, the comparison of irrigation duration per plot with the predetermined rules for water management on a yearly scale $(2012 / 2013)$ (figure 8 ) showed that $77 \%$ of the plots in sector $1,75 \%$ of the plots in sector 2 and $81 \%$ of the plots in sector 3 exceeded the current rule of $9 \mathrm{~h} \cdot \mathrm{ha}^{-1}$.

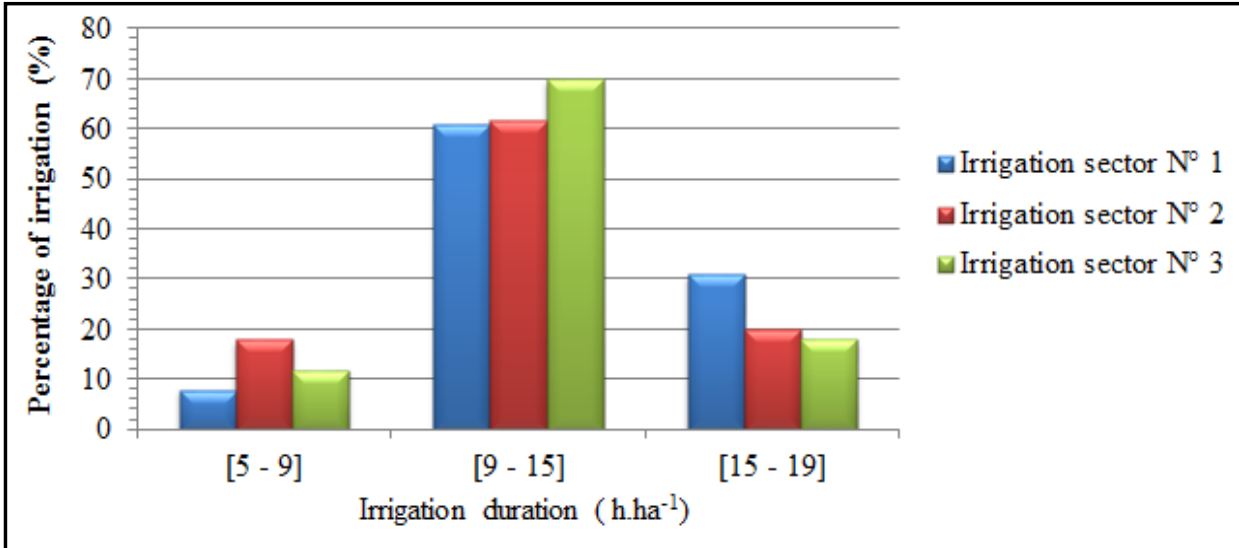

Figure 8- Histogram of irrigation duration with respect to current rule of $9 \mathrm{~h} \cdot \mathrm{ha}^{-1}$ (number of irrigated plots: 150, number of irrigation events: 1429, agricultural year 2012/2013).

This considerable increase in irrigation duration is the main factor of the recorded low water delivery turn. Often, the farmers (older than 60 years and had generally low school education level) disregarded the rules imposed by the Water Users' Association and didn't know the negative effects of this high irrigation duration (especially the dysfunction of irrigation practice and the degradation of soil resources) (Ghazouani et al, 2009). So, the farmers need to be made aware of the current overexploitation of the water resource (Marlet et al, 2009).

\section{Overall irrigation efficiency $\left(\mathrm{E}_{\mathbf{0}}\right)$}

The characterization of irrigation performance from the well to the plot during the year of study (figure 9) shows well that the "poor" overall irrigation efficiency $\left(\mathrm{E}_{\mathrm{o}}=28.41 \%\right)$ is affected mainly by the bad water management in the plots (farmer's practices) and by the important dysfunction of the secondary hydraulic network. At the irrigation scheme level, the water delivery turn is affected by the high irrigation duration in the 
irrigated plots and the technical dysfunctions of the irrigation network. At the plot scale, the problem is mainly caused by the poor maintenance of irrigation system (absence of water saving systems of some plots, bad land leveling of irrigation basins...etc.) and also by some environmental conditions like the soil type and the climatic conditions.

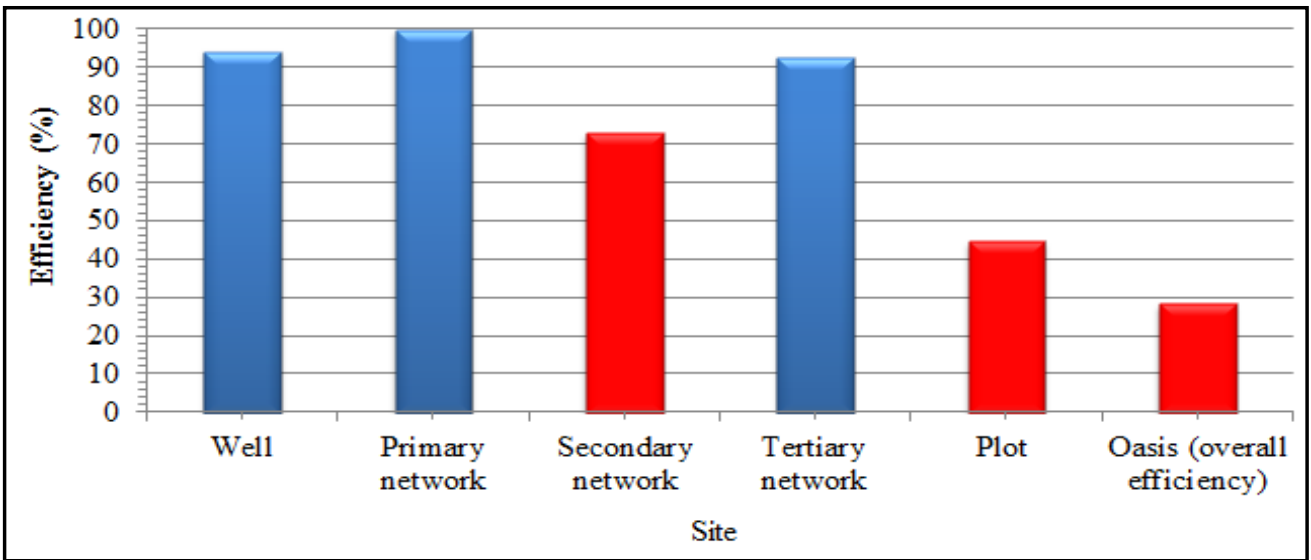

Figure 9- Irrigation performance from the well to the plot during the study year

\section{Conclusion}

Problems of irrigation efficiency are common to almost Douz oases (Southern Tunisia). The Lazala oasis is a representative example of this problem which is nearly similar for the majority of irrigated area in the region. The present study is a contribution to better understand the hydraulic working of this communitymanaged irrigation scheme. Obtained results showed that the irrigation was inefficient (the application irrigation efficiency was $44.6 \%$ ) and relatively uniform (the mean $\mathrm{D}_{\mathrm{U}}$ was $67 \%$ ). However, the results showed that the well and the irrigation method (surface irrigation) can easily satisfy the crop water requirements. Consequently, the studied oasis needs only to improve the management and the water control in the plots (knowing how much water to apply, scheduling irrigations and sharing the saving water systems in the totality of irrigated areas), and to assure the continuous maintenance of the hydraulic network (especially the secondary irrigation network).

\section{Acknowledgements}

The authors sincerely thank the farmers' owners of experimental plots for his availability and kind welcome. The authors would like to express also their thanks to Mr. A. Gandouzi (Soil Resources Department) from the Regional Commissar for Agricultural Development of Kebili/Agriculture Ministry (Tunisia) for the help and the technical support.

\section{References}

[1]. Abbasi F., Heydari N., Sohrab F., 2011. Evaluating irrigation efficiency and ISO-efficiency maps in Iran.21 $1^{\text {st }}$ International Congress on Irrigation and Drainage, 15-23 October 2011, Tehran, Iran, R.56.1.16

[2]. Allen R.G., Willardson L.S., Fredriksen H.D., 1997. "Water use definitions and their use for assessing the impacts of water conservation" In: deJager JM, Vermes LP, Ragab R (Eds.) Proceedings of the ICID Workshop "Sustainable Irrigation in Areas of Water Scarcity and Drought", Oxford, England, 1997, p. 72-80

[3]. Askri B., Bouhlila R., 2010. Evolution de la salinité des oasis modernes de la Tunisie. Etude et gestion des sols, volume 17, 34,2010, p. 197- 212

[4]. Bouaziz A., Belabbes K., 2002. Efficience productive de l'eau en irrigue au Maroc. Revue H.T.E.N ${ }^{\circ}$ 124, p. 57- 72

[5]. Burt C.M., Clemmens A.J., Strelkoff T.S., Solomon K.H., Howell L.T., Eisenhauer D., Bleisner R., 1997. Irrigation performance measures: Efficiency and uniformity. J Irrigation and Drainage Engineering 123(6): 423-442

[6]. CRUESI., 1970. Recherche et formation en matière d'irrigation avec des eaux salées, 1962-1969, Rapport technique, 243 p.

[7]. FAO., 1989. Guidelines for designing and evaluating surface irrigation systems, FAO, Irrigation and Drainage, paper 45. Available at www.fao.org

[8]. Gharbi N., 2010. Aménagements hydrauliques et amélioration de la gestion de l'eau dans les oasis du sud. Actes de l'atelier Sirma « Gestion des ressources naturelles et développement durable des systèmes oasiens du Nefzaoua », 25-27 février 2009, Douz, Tunisie. Cirad, Montpellier, France, 05 p.

[9]. Ghazouani W., Marlet S., Mekki I., Vidal A., 2007. Diagnostic et analyse du fonctionnement d'un périmètre oasien. Cas de l'oasis de Fatnassa Nord (Kébili, sud Tunisien). Actes du troisième atelier régional du projet SIRMA, Cirad, Montpellier, France, colloques -cédérom, Nabeul, Tunisie, $18 \mathrm{p}$.

[10]. Ghazouani W., Marlet S., Mekki I., Vidal A., 2009. Farmers' perceptions and engineering approach in the modernization of a community-managed irrigation scheme. A case study from an oasis of the Nefzawa (South of Tunisia).Irrigation and Drainage 58: S285-S296

[11]. Haman D.Z., Smajstrla A.G., Pitts D.J., 2003.Uniformity of Sprinkler and Micro irrigation Systems for Nurseries.BUL321, Florida Cooperative Extension Service University of Florida

[12]. Heermann D.F., Wallender W.W., Bos M.G., 1990. Irrigation Efficiency and Uniformity; In: Management of Farm Irrigation Systems; Hoffman GJ, Howell TA, Solomon KH, Eds.; Am. Soc. Agric. Engrs.: St. Joseph, MI, 1990; $125-149$. 
[13]. Irmak Suat., Kranz William L., Eisenhauser Dean E., 2011. Irrigation efficiency and uniformity, and crop water use efficiency, Publication EC732, University of Nebraska -Lincoln Extension. Available at: http://extension.unl.edu/publications

[14]. J.G Van Alphen., F de los Rios Romero., 1971.Gypsiferous soils: Notes on their characteristics and management. International Institute for Land Reclamation and Improvement / WAGENINGEN / THE NETHERLANDS / Bulletin 12

[15]. Kanber R., Ünlü M., Cakmak E.H., Tüzün M., 2005. Irrigation systems performance: Turkey country report. In: Lamaddalena N., (ed.), Lebdi F., (ed.), Todorovic M., (ed.), Bogliotti C., (ed.). Irrigation systems performance. Bari: CIHEAM, 2005. p. 205-226 (Options Méditerranéennes : Série B. Etudes et Recherches; $n$. 52)

[16]. Kassah A., 1996. Les oasis tunisiennes : aménagement hydro-agricole et développement en zone aride. Faculté des lettres et sciences humaines de Tunis 13é série : Géographie, $346 \mathrm{p}$.

[17]. Louhichi K., 1999. Amélioration de l'efficience de l'irrigation pour une économie d'eau : cas d'un périmètre irrigué en Tunisie, Rapport final, Plan d'action pour la méditerranée, CIHEAM-IAMM, PNUE/Plan bleu, 59 p.

[18]. Liebenbag P.J., Zaid A., 2002. Date balm, FAO, Plant Production and Protection, papers 156 Rev. 1

[19]. Marlet S., Bouksila F., Mekki I., Ben Aissa I., 2007. Fonctionnement et salinité de la nappe de l'oasis de Fatnassa: arguments géochimiques. In: Actes du troisième atelier régional du projet SIRMA, Kuper M, Zairi A (eds), Nabeul, Tunisie

[20]. Marlet S., Bouksila F., Bahri A., 2009. Water and salt balance at irrigation scheme scale: a comprehensive approach for salinity assessment in a Saharan oasis. Agricultural Water Management 96: 1311-1322

[21]. Mekki I., Jacob F., Marlet S., Ghazouani W., 2009. Analyzing oases sustainability in Tunisia the case of the Nefzawa regionSubmitted to Regional environmental change

[22]. Merriam J.L., and Keller J., 1978. Farm irrigation system evaluation: A guide for management, Utah State Univ, Logan, UT. 271pages

[23]. OMRANI N., OUESSAR M., 2004. Technical perspectives of irrigation efficiency improvement in the oasis systems: cases of Southern Tunisia. In: El Moujabber M (ed.), Mandi L., (ed.), Trisorio-Liuzzi G., (ed.), Martín I., (ed.), Rabi A., (ed.), Rodríguez R., (ed.), Technological perspectives for rational use of water resources in the Mediterranean region. Bari: CIHEAM., 2009, pp 267274 (Options Méditerranéennes : Série A. Séminaires Méditerranéens; n. 88)

[24]. Rhoades J.D., 1974. Drainage for salinity control pp. 433-462. In: Drainage for agriculture (J. van Schilfgaarde, ed.), Amer.Soc. Agron. Monograph17. Madison, WI: Amer. Soc. Agron.

[25]. Saeed M.M., Ashraf M., Bruen M., 2002. Diagnostic analysis of farmers' skimming well technologies in the Indus Basin of Pakistan. Irrigation and Drainage Systems 16.pp 139-160

[26]. SASS., 2003. Système aquifère de Sahara Septentrional, 2ème édition, Volume II, Hydrogéologie

[27]. Sghaier M., 1995. Les agrosystèmes de production oasiens et leur rôle socio-économique, cas des oasis tunisiennes. In Désertification et Aménagement au Maghreb, Coude-Gaussen G., Rognon P., (eds). Hartmann: Paris

[28]. Sghaier M., 1999. Les Oasis de la Région de Nefzaoua. IMAROM Working Paper Series no 3, August 1999

[29]. Solomon K.H., 1983. Irrigation uniformity and yield theory, PhD thesis, Utah State Univ., Logan, Utah. 